\title{
Reproductive indices in natural nests of giant Amazon river turtles Podocnemis expansa (Schweigger, 1812) (Testudines, Podocnemididae) in the Environmental Protection Area Meanders of the Araguaia river
}

(With 4 Figures)

\begin{abstract}
A count was made of unhatched eggs and hatchling live and dead Podocnemis expansa turtles in 327 natural nests located on the beaches of the Environmental Protection Area (EPA) Meanders of the Araguaia River, to determine the percentage of hatching (94.63\%), non-hatching (5.37\%), survival (94.24\%) and hatchling mortality (5.76\%), and the average percentage of dead hatchlings during the 15 days in the nursery $(0.97 \%)$. The mean number of hatchlings per nest was determined from the sum of the number of live and dead hatchlings divided by the total number of nests, while the mean number of eggs per nest was determined from the sum of live and dead hatchlings and unhatched eggs divided by the number of nests. These calculations yielded the following mean values: live hatchlings $(88.98 \pm 23.94)$, dead hatchlings $(0.37 \pm 0.93)$, unhatched eggs (5.07 \pm 9.57$)$, and total number of eggs $(94.42 \pm 21.30)$. The reproductive efficiency of the wild population of $P$. expansa can be affected by many environmental factors such as temperature, humidity and rainfall. In addition, man-made factors like the presence of chemicals in the water and the potential for infectious disease also have significant impact. The reproductive indices data obtained from this study are indispensable for future investigations of hatching anomalies.
\end{abstract}

Keywords: hatching, nests, reproduction, reptile, survival.

\section{Índices reprodutivos em ninhos naturais de tartarugas da Amazônia Podocnemis expansa (Schweigger, 1812) (Testudines, Podocnemididae), na Área de Proteção Ambiental Meandros do Rio Araguaia}

\begin{abstract}
Resumo
Realizou-se a contagem dos ovos não eclodidos, dos filhotes vivos e mortos de Podocnemis expansa oriundos de 327 ninhos naturais, localizados nas praias da Área de Proteção Ambiental (APA) - Meandros do Rio Araguaia, onde se determinou a porcentagem de eclosão dos ovos (94,63\%); não eclosão (5,37\%); sobrevivência (94,24\%) e mortalidade dos filhotes $(5,76 \%)$, e a média de filhotes mortos durante os 15 dias no berçário $(0,97 \%)$. A média do total de filhotes por ninho foi determinada pela soma do número de filhotes vivos e mortos divididos pelo total de ninhos, enquanto que a média do total de ovos por ninho foi determinada pela soma do número de filhotes vivos, mortos e ovos não eclodidos divididos pelo total de ninhos. Com isso, obtiveram-se os valores médios do número de filhotes vivos $(88,98 \pm 23,94)$; mortos $(0,37 \pm 0,93)$; ovos não eclodidos $(5,07 \pm 9,57)$, e total de ovos $(94,42 \pm 21,30)$. A eficiência reprodutiva da população selvagem de $P$. expansa pode ser afetada por muitos fatores ambientais, como temperatura, umidade e precipitação. Além disso, fatores influenciados pelo homem, como a presença de produtos químicos na água e a possibilidade de doenças infecciosas, também têm impacto significativo. Os dados dos índices reprodutivos obtidos neste estudo são indispensáveis para futuras investigações de anomalias de incubação.
\end{abstract}

Palavras-chave: eclosão, ninhos, reprodução, reptile, sobrevivência. 


\section{Introduction}

The nesting behaviour of the giant Amazon river turtle comprises seven phases: aggregation of the population in shallow waters close to the nesting beach; climb up the beach to sunbathe during the warm hours of the day; climb up the beach at night to scout and select the nesting site; excavation of the nest; egg laying; backfilling and tamping the egg chamber; and return to the water (Vanzolini, 1967; Alho et al., 1979; Alho and Pádua, 1982a).

The reproduction of the family Podocnemididae depends on the annual flooding and ebbing cycle, with egg-laying and incubation occurring in the dry season and hatching coinciding with the onset of rising rivers (Alho and Pádua, 1982a; Fachín-Terán, 1992; Thorbjarnarson et al., 1993). The onset of falling water levels appears to be the stimulus that triggers the migration of female Podocnemis expansa to the nesting site, since adults are found in lakes during the flood period and aggregated in rivers in the dry season (Alho and Pádua, 1982a,b).

Although the status of natural populations is unknown, the basis of turtle preservation activities involves nest and hatchling protection and management (Crouse et al., 1987), since predation pressure occurs mainly in these phases of the life cycle of these reptiles (Grand and Beissinger, 1997).

According to Gibbons (1970), for aquatic chelonians, the path from the nest to the water represents their main battle for survival, for hatchlings are at their most vulnerable along this trajectory, where they may be attacked by a variety of predators.

In view of the above information, the objective of this study was to determine the percentage of hatched and unhatched eggs, hatchling survival and mortality, and the average number of live and dead hatchlings, unhatched eggs and total number of eggs of $P$. expansa from natural nests in the Environmental Protection Area (EPA) of Meanders of the Araguaia River, state of Goiás, Brazil.

\section{Material and Methods}

Under SISBIO (System of Authorization and Information about Biodiversity) permit number 13447 , the $P$. expansa nesting beaches in the Meanders of the Araguaia river EPA (13 $17^{\circ}$ '49.0" S and 50 36' 16.5" W until 13०30'00.0" S and $\left.50^{\circ} 43^{\prime} 29.51^{\prime \prime} \mathrm{W}\right)$, located in district of Luiz Alves, municipality of São Miguel do Araguaia, Goiás State, Brazil, were labelled with signs in alphabetical order (Figure 1) in the second half of September 2008.

The beaches were monitored daily in the morning to detect and identify egg-laying during the previous night, using numbered stakes (Figure 2). This work was concluded in the first half of October of the same year, when all the females had spawned, making a total of 327 nests.

Opening of the nests began in the second half of November and ended in the second half of December 2008. The hatchlings were removed from the egg chambers and counted only when they were considered "mature", i.e., when their vitellus was completely absorbed (Figure 3 ).

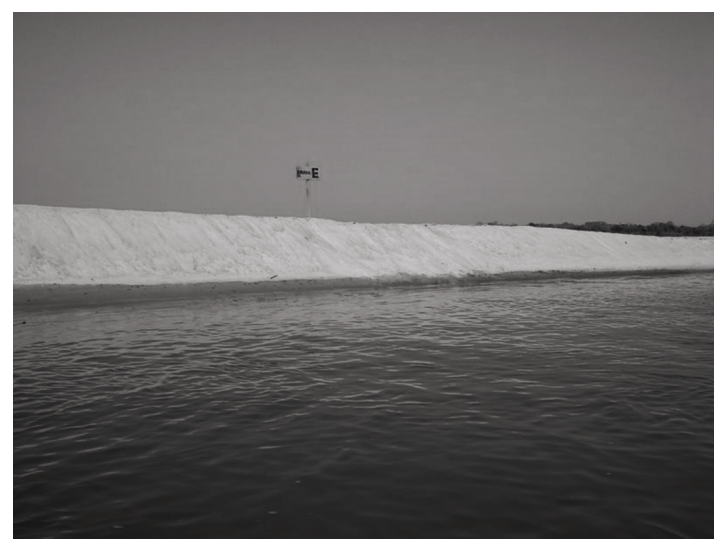

Figure 1. Nesting beach labelled with signs in alphabetical order.

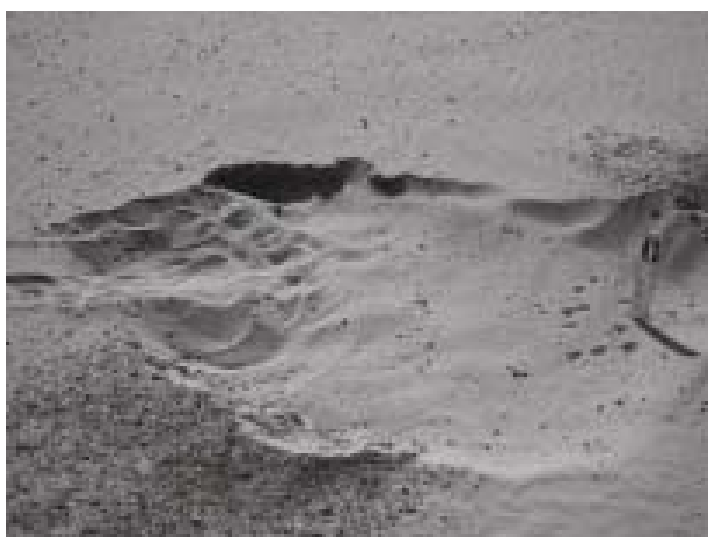

Figure 2. Nest marked with a numbered stake.

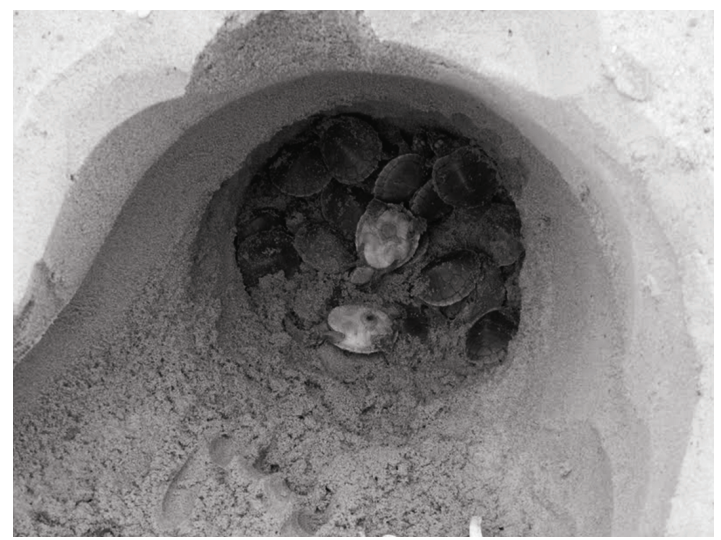

Figure 3. Egg chamber containing "mature" hatchlings.

Each beach was identified with a sign and each nest was also marked with a identification number and the date of hatching. This information was consolidated in a spread sheet. Also recorded in the spread sheet was the number of live hatchlings, dead hatchlings and unhatched eggs.

The hatchlings removed from the egg chambers were taken to a nursery located at the headquarters of the Projeto 
Quelônios da Amazônia (Amazonia Chelonia Project) of the Meanders of the Araguaia river EPA, where they were kept for 15 days to lose their egg odor, after which they were released on the riverbank.

The total number of hatchlings was determined by adding up the live and dead hatchlings, while the total number of eggs was determined by adding the live and dead hatchlings and the unhatched eggs. The hatchlings released on the riverbank were the ones that survived the 15 days in the nursery.

The data were evaluated from mean values and standard deviation.

\section{Results}

A total of 29,538 live hatchlings were collected from the nests and after the two-week period in the nursery, 29,251 were released on the banks of the Araguaia, representing a mortality rate of $0.97 \%$ in the nursery. Hatched eggs represented $94.63 \%$ and unhatched eggs $94.63 \%$, while survival and mortality rates were 94.24 and $5.76 \%$, respectively. Oil eggs were not observed in the evaluated nests.

The mean values found per nest were: live hatchlings (88.98 \pm 23.94$)$, dead hatchlings $(0.37 \pm 0.93)$, unhatched eggs $(5.07 \pm 9.57)$ and total number of eggs $(94.42 \pm 21.30)$, as indicated in Table 1.

\section{Discussion}

Valle et al. (1973) and Alho et al. (1979) verified some $P$. expansa nests presented up to 5 abnormal eggs. Abnormalities included absence of embryo, diameter greater than $5 \mathrm{~cm}$ and eggs with content intact even after incubation period. Eggs with these abnormalities are referred to as oil eggs (Alho et al., 1979). The shape of oil eggs can be elliptical, spherical, oval and even similar to the shape of a bowling pin (Molina and Gomes, 1998).

According to Hirth (1980) the marine chelonias spawning nests present abnormal eggs in the superficial layer of the nest, suggesting they are intended as sacrifice to satiate predators. But Krause et al. (1982) found abnormal eggs in both in the superficial and interior layers of Trachemis dorbignyi (water tiger) nests suggesting the distribution aids the conservation of the nest microclimate. In the present study, oil eggs were not observed in the evaluated nests to support or refute the previous studies.

The mean total number of eggs and of dead hatchlings per female were lower than those reported by Lima
(2007) at the Tabuleiro do Abufari, state of Amazonas, between 1998 and 2004, which were $106.70 \pm 28.38$ and $4.00 \pm 9.50$, respectively. However, the mean number of live hatchlings and the hatching rate in the Meanders of the Araguaia River EPA were higher than those found by the aforementioned author, who reported values of $66.00 \pm 39.70$ and $77.80 \%$.

In studies conducted by Malvásio et al. (2005) in the Javaés river, state of Tocantins, the mean number of eggs per nest was higher $(109.89 \pm 19.37)$ than in the present study, although similar values (91.5) were found by Alho and Pádua (1982b) in the Trombetas river, state of Pará.

The high standard deviation in the number of dead hatchlings and unhatched eggs found in this study was attributed to the total loss of five nests (Figure 4). This loss was caused by the low level of these nests in relation to the water sheet of the Araguaia River, which resulted in their partial inundation, altering the proper humidity coefficient for embryo development. According to Alho and Pádua (1982b), the sudden and unpredictable flooding (swell of rising water) of the Trombetas river in 1980 eliminated $99 \%$ of the embryos, while the normal hatching rates in previous years was, on average, $95 \%$.

Even at risk of inundation, the five nests of this study were not translocated. According to Lustosa (2008, personal observation), no relevant alterations were found in hatching and hatchling survival rates after handling several egg chambers, but the number of malformed hatchlings was considerably higher than among non-handled nests. Valenzuela et al. (1997) stated that translocating eggs may also interfere in determining the sex of hatchlings,



Figure 4. Egg chamber lost due to sudden flooding of the Araguaia River.

Table 1. Mean values and standard deviation of the reproductive indices of natural nests of Podocnemis expansa in the Meanders of the Araguaia River EPA.

\begin{tabular}{ccc}
\hline Reproductive indices & Mean $(\boldsymbol{\%})$ & Standard deviation $(\boldsymbol{\%})$ \\
\hline Live hatchlings & 88.98 & 23.94 \\
Dead hatchlings & 0.37 & 0.93 \\
Unhatched eggs & 5.07 & 9.57 \\
Total eggs & 94.42 & 21.30 \\
\hline
\end{tabular}


which is directly related to the temperature of incubation. Malvásio et al. (2005) found that handling $P$. expansa eggs and exposing them to variations in temperature and humidity may interfere in the formation of the embryo. These authors reported that handling involving measuring and rotating of eggs interferes negatively in the hatching rate. Moreover, such handling may lead to predation of turtle embryos by fly larvae introduced accidentally into the egg chamber (Pezzuti, 1998).

Salera Júnior et al. (2009) observed that on their journey to the water, newly hatched $P$. expansa turtles are attacked predominantly by birds of the genus Coragyps and the species Polyborus plancus, which engage in individual or group aerial attacks, capturing hatchlings close to their nests. These authors also observed that the species Jabiru mycteria and Mycteria americana, which are larger, swallow the hatchlings whole, while the smaller species such as Coragyps atratus devour them in pieces, leaving only the empty shell on the sand. This fact demonstrates the importance of capturing hatchlings while they are still in their egg chambers, as the team of the Chico Mendes Institute for Biodiversity Conservation (ICMBio) does to mitigate the predation rate.

The most common predators of $P$. expansa eggs and hatchlings are the black-headed vulture (Coragyps atratus), the red-headed vulture (Cathartes aura), the lesser yellowheaded vulture (Cathartes burrovianus), the carcara plancus (Polyborus plancus), the yellow-headed caracara (Mivalgo chimachima), the jabiru stork (Jabiru mycteria), the wood stork (Mycteria americana), the maguari stork (Ciconia maguari) and the great white egret (Casmerodius albus) (Salera Júnior et al., 2009). These authors also found mild predation by the tegu lizard (Tupinambis teguixin), the ring-tailed coati (Nasua nasua), crab-eating fox (Cerdocyon thous), cocoi heron (Ardea cocoi), snowy egret (Egretta thula) and the rufescent tiger-heron (Tigrisoma lineatum).

Piranhas of the genus Serrasalmus spp. stand out as aquatic predators of hatchling turtles (Salera Júnior et al., 2009), but other predators may be frogs (Buffo sp.), caimans (Paleosuchus spp., Caiman crocodilus) and carnivorous fish such as long-whiskered catfish (Pimelodidae), red-tailed catfish (Phractocephalus hemiliopterus), silver arowana (Osteoglossum bicirrhosum), piraiba (Brachyplatystoma filamentosum) and jau (Paulicea luetkeni) (Ibama, 1989).

Cantarelli and Herde (1989) and Andrade (2004) state that hatchlings should be kept in nurseries for periods of up to 15 days, sufficient time for hardening of the carapace, umbilical cicatrisation and elimination of the characteristic strong odor of the fat of the egg. This procedure hinders predation by natural enemies and increases the chances of survival of hatchlings, thus justifying keeping them for 15 days in the nursery of the Meanders of the Araguaia river EPA in order to reduce predation pressure.

According to Crouse et al. (1987), the phase of life of chelonians to be prioritized in management programs for threatened populations has still not been defined.
Crouse et al. (1987) and Brooks et al. (1991) stated that, from the demographic viewpoint, there is no point in focusing on the protection of eggs and hatchlings. However, Grand and Beissinger (1997) claim that both conservation and recovery of native populations depend on the protection of nests and hatchlings, since predation pressure occurs mainly in these phases of the life cycle of these animals. Therefore, the conservation and management programmes conducted by ICMBio at the Meanders of the Araguaia river EPA are of fundamental importance for the recovery and preservation of the natural populations of $P$. expansa in the state of Goiás, Brazil.

In general, excessive management of the reproductive process of chelonians can impair the trophic chain and interfere in the population dynamics of other species existing at a location, insofar as it changes the availability of food, and is therefore not recommended.

The reproductive efficiency of the wild population of $P$. expansa can be affected by many environmental factors such as temperature, humidity and rainfall. In addition, men-maid factors like the presence of chemical in the water and the potential for infectious disease also have significant impact. The reproductive indices data obtained from this study are indispensable for future investigations of hatching anomalies.

\section{References}

ALHO, CJR., CARVALHO, AG. and PÁDUA, LFM. 1979. Ecologia da tartaruga da Amazônia e avaliação de seu manejo na Reserva Biológica do Trombetas. Brasil Florestal, vol. 9, no. 38 , p. $29-47$

ALHO, CJR. and PÁDUA, LFM., 1982a. Reproductive parameters and nesting behavior of the Amazon turtle Podocnemis expansa (Testudinata: Pelumedusidae) in Brazil. Canadian Journal of Zoology, vol. 60, no. 2, p. 97-103.

-, 1982b. Sincronia entre o regime de vazante do rio e o comportamento de nidificação da tartaruga da Amazônia Podocnemis expansa (Testudinata: Pelomedusidae). Acta Amazônica, vol. 12 , no. 2 , p. $323-326$

ANDRADE, PCM., 2004. Criação e Manejo de Quelônios no Amazonas. Brasil: Ibama, Ufam, SDS. p. 492. Projeto Diagnóstico de Animais Silvestres no Estado do Amazonas.

BROOKS, RJ., BROWN, GP. and GALBRAITH, DA., 1991. Effects of a sudden increase in natural mortality of adults on a population of the common snapping turtle (Chelydra serpentina). Canadian Journal of Zoology, vol. 69, p. 1314-1320. http://dx.doi. org/10.1139/z91-185

CANTARELLI, VH. and HERDE, LC., 1989. Projeto quelônios da Amazônia - 10 anos. Brasília: IBAMA. 122 p.

CROUSE, DT., CROWDER, LB. and CASWELL, H., 1987. A stage-based population model for loggerhead sea turtles and implications for conservation. Ecology, vol. 68, no. 5, p. 14121423. http://dx.doi.org/10.2307/1939225

FACHÍN-TERÁN, A., 1992. Desove y uso de playas para nidificación de taricaya (Podocnemis unifilis) en el rio Samiria, Loreto-Perú. Boletin de Lima, vol. 79, p. 65-75. 
GIBBONS, JW., 1970. Terrestrial activity and the population dynamics of aquatic turtles. The American Midland Naturalist, vol. 83, no. 2, p. 404-414. http://dx.doi.org/10.2307/2423953

GRAND, J. and BEISSINGER, SR., 1997. When relocation of loggerhead sea turtle (Caretta caretta) nests becomes a useful strategy. Journal of Herpetology, vol. 31, p. 428-434. http:// dx.doi.org/10.2307/1565674

HIRTH, HF., 1980. Some aspects of nesting behavior and reproductive biology of sea turtles. American Zoologist. vol. 20, p. $507-523$.

Instituto Brasileiro do Meio Ambiente e dos Recursos Naturais Renováveis - IBAMA, 1989. Projeto Quelônios da Amazônia: Manual Técnico. Brasília: IBAMA. p. 125.

KRAUSE, L., GOMES, N. and LEYSER, KI., 1982. Observações sobre a nidificação e desenvolvimento de Chrysemys dorbignyi (Dumeril \& Bibron, 1835) (Testudines, Emididae) na Estação Ecológica do Taim, Rio Grande do Sul. Revista Brasileira de Zoologia, vol. 4, no. 1, p. 79-90.

LIMA, JP., 2007. Aspectos da biologia reprodutiva de Podocnemis expansa Schweigger 1812, Podocnemis sextuberculata Cornalia, 1849 e Podocnemis unifilis Troschel, 1848 (Testudines, Podocnemididae) na reserva biológica do Abufari, Amazonas, Brasil. Manaus: Instituto Nacional de Pesquisas da Amazônia. Dissertação de Mestrado em Ecologia.

MALVÁSIO, A., SALERA JÚNIOR, G., SOUZA, AM. and MODRO, NR., 2005. Análise da interferência do manuseio dos ovos no índice de eclosão e no padrão de escutelação do casco e as correlações encontradas entre as medidas das covas, ovos e filhotes em Podocnemis expansa (Schweigger, 1812) e P. unifilis
(Troschel, 1848) (Testudines, Pelomedusidae). Publicações avulsas do Instituto Pau Brasil de História Natural, vol. 8, no. 10, p. 15-38.

MOLINA, FB. and GOMES, N., 1998. Incubação artificial dos ovos e processo de eclosão em Trachemys dorbignyi (Duméril \& Bibron) (Reptilia, Testudines, Emydidae). Revista Brasileira de Zoologia, vol. 15, no. 1, p. 135-143.

PEZZUTI, JCB., 1998. Ecologia reprodutiva da iaçá, Podocnemis sextuberculata (Testudines, Pelomedusidae) na RDSM, Amazonas, Brasil. Manaus: Instituto Nacional de Pesquisas da Amazônia. Dissertação de Mestrado.

SALERA JÚNIOR, G., MALVÁSIO, A. and PORTELINHA, TCG., 2009. Avaliação da predação de Podocnemis expansa e Podocnemis unifilis (Testudines, Podocnemididae) no rio Javaés, Tocantins. Acta Amazônica, vol. 39, no. 1, p. 207-214.

THORBJARNARSON, JB., PEREZ, N. and ESCALONA, T., 1993. Nesting of Podocnemis unifilis in the Capanaparo River, Venezuela. Journal of Herpetology, vol. 27, no. 3, p. 344-347. http://dx.doi.org/10.2307/1565161

VALENZUELA, N., BOTERO, R. and MARTINEZ, E., 1997. Field study of sex determination in Podocnemis expansa from Colombian Amazonia. Herpetologica, vol. 53, no. 3, p. 390-398.

VALLE, RC., ALFINITO, J. and SILVA, MMF., 1973. Contribuição ao estudo da tartaruga amazônica: Preservação da tartaruga da Amazônia. Belém: Ministério da Agricultura, DEMA/PA, IBDF. p. 66-88.

VANZOLINI, PE., 1967. Notes on the nesting behavior of Podocnemis expansa in the Amazon valley (Testudines, Pelomedusidae). Papéis Avulsos de Zoologia, vol. 20, p. 191-215. 
